University of Nebraska - Lincoln

DigitalCommons@University of Nebraska - Lincoln

March 2002

\title{
Procoilodes adrastus Ocampo, a New Genus and Species of Miocene Hybosorid in Amber from the Dominican Republic (Coleoptera: Scarabaeoidea: Hybosoridae)
}

\author{
Federico C. Ocampo \\ University of Nebraska - Lincoln, focampo2@unl.edu
}

Follow this and additional works at: https://digitalcommons.unl.edu/entomologypapers

Part of the Entomology Commons

Ocampo, Federico C., "Procoilodes adrastus Ocampo, a New Genus and Species of Miocene Hybosorid in Amber from the Dominican Republic (Coleoptera: Scarabaeoidea: Hybosoridae)" (2002). Papers in Entomology. 125.

https://digitalcommons.unl.edu/entomologypapers/125

This Article is brought to you for free and open access by the Museum, University of Nebraska State at DigitalCommons@University of Nebraska - Lincoln. It has been accepted for inclusion in Papers in Entomology by an authorized administrator of DigitalCommons@University of Nebraska - Lincoln. 


\title{
Procollodes adrastus OCampo, a New Genus and Species of Miocene Hybosorid in AMber from the Dominican RepUblic (COLEOPTERa: ScarabaeoIdea: Hybosoridae)
}

\author{
Federico C. OCAMPo \\ Systematics Research Collections, W 436 Nebraska Hall \\ University of Nebraska State Museum \\ Lincoln, NE 68588, U.S.A. \\ focampo@unlserve.unl.edu
}

\begin{abstract}
Procoilodes adrastus Ocampo (Coleoptera: Scarabaeoidea: Hybosoridae), a new genus and species of fossil hybosorid, is described from the Dominican Republic. The fossil is embedded in amber resin of Hymenaea protera Poinar (Leguminosae) and dates from the Miocene.
\end{abstract}

\section{Resúmen}

Se describe Procoilodes adrastus Ocampo (Coleoptera: Scarabaeoidea: Hybosoridae), un nuevo género y especie de hybosórido de República Dominicana. Este fósil esta incluído en ambar originado de la resina de Hymenaea protera Poinar (Leguminosae) y data del Mioceno.

"... it is our awe at the miracle of time that allows something in us to endure, never moving." Jorge Luis Borges

Tyrannasorus rex Ratcliffe and Ocampo (2001) was the first fossil hybosorid described from the Dominican Republic. I describe the second hybosorid fossil from this region, Procoilodes adrastus Ocampo, n. gen., n. sp. According to Ivie (1998), four species of extant Hybosoridae occur in the West Indies: Hybosorus illigeri Reiche (1853), introduced from the Old World during the past century, Apalonychus rufulus (Castelnau 1840), A. waterhousei Westwood (1846), and Coilodes nigripennis Arrow (1903). Iturralde-Vinent and MacPhee (1999) suggested that northwestern South America was briefly connected to large landmasses emergent on the Greater Antilles Ridge and Avis Ridge during the Eocene-Oligocene transition (35-33 mya). Subsequently, these landmasses became subdivided as a result of tectonics, possibly resulting in multiple instances of vicariance. This scenario may also explain past and present distributions of hybosorids in the West Indies.

The following description lacks some detail because certain characters of the body cannot be seen due the dark nature of the amber in which it is embedded.

\section{Procoilodes Ocampo, new genus}

Type Species. Procoilodes adrastus Ocampo, here designated.

Description. Scarabaeoidea, Hybosoridae. Body form (Fig. 1) convex. Color dark brown. Head. Frons finely tuberculate, lateral margin narrowly reflexed. Clypeus with anterior margin rounded, margins reflexed. Labrum protruding past clypeal apex, weakly pointed. Eyes slightly visible in dorsal view. Antennae (Fig. 4) 10-segmented; basal 

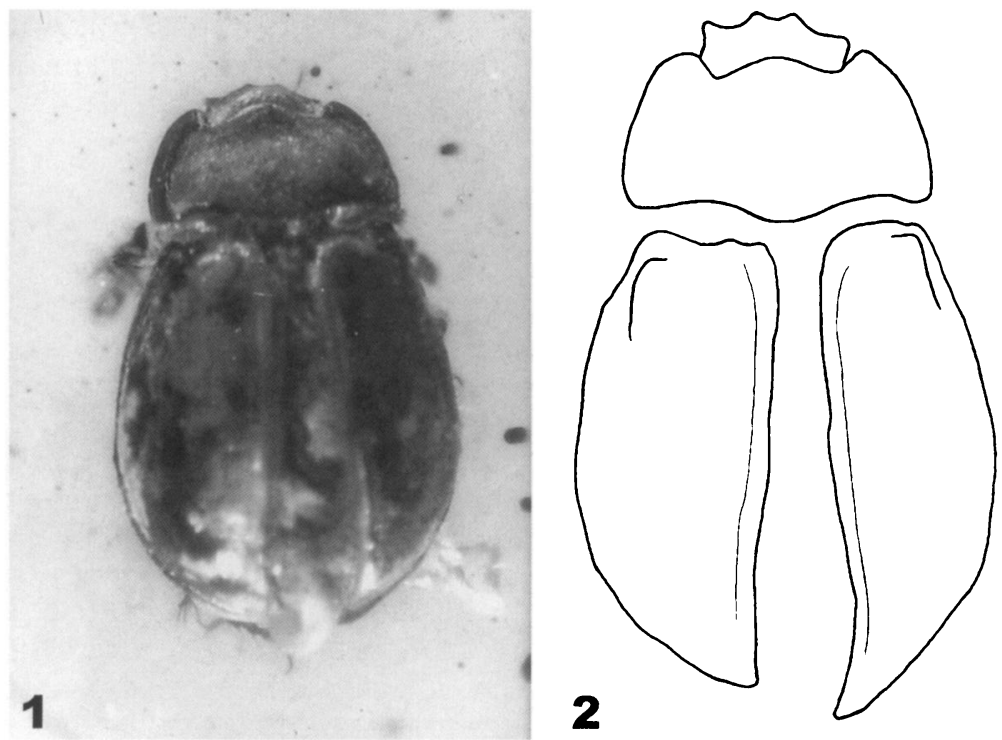

3
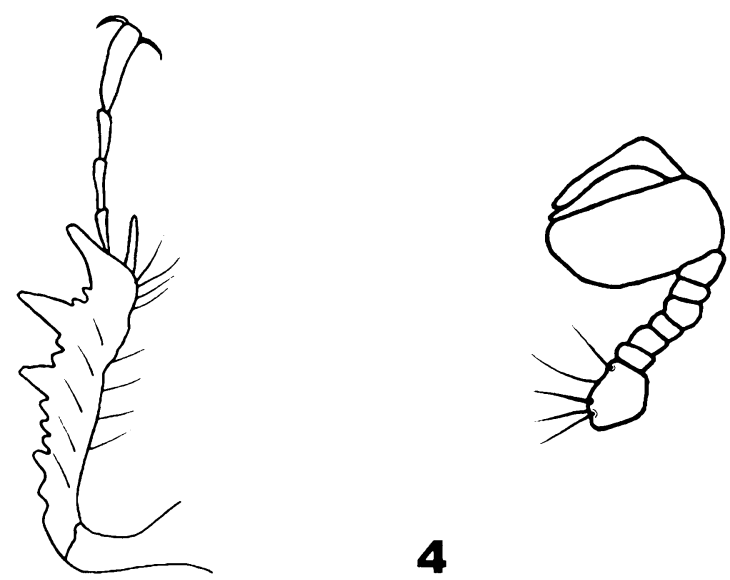

Fig. 1. Holotype of Procoilodes adrastus embedded in amber, dorsal view.

Figs. 2-4. Procoilodes adrastus. 2) Dorsal view of head and pronotum; 3) dorsal view of left foreleg; 4) dorsal view of right antenna.

segment apically expanded, with long erect setae on anterior side; second and third segments longer than wide; fourth to sixth segments broader than long; club 3-segmented, with first segment cupuliform and able to receive second and half of third segments; all segments with short and sparse setae. Pronotum. (Figs. 1-2) Surface weakly convex. Anterior margin sinuate; anterior angles strongly produced, subacutely rounded; lateral margins rounded, widest just behind middle; posterior margin sinuate, produced backward at middle. Scutellum. Surface heavily and finely tuberculate. Elytra. Shape convex, subglobose. Lateral margins curved, widest at middle, with marginal bead. Humeral umbone well developed. Wings: 1 wing protruding, well-developed. Legs. Meso- 
and metatibiae with transverse ridge near middle of external surface; ridge with thick erect setae on margin; apex truncate, dilated, with a large, rounded lobe on its external edge with crown of long, thick setae, with 2 apical spurs; spurs longer than first tarsal segment, internal spur longer than external. All claws simple.

Remarks. The genus Procoilodes is unique among other hybosorids from the West Indies because of its finely tuberculate frons. The genus Procoilodes is similar to the genera Apalonychus, Coilodes, and Tyrannasorus in the following characters: body form convex; apex of meso- and metatibiae truncate, dilated, and with a large, rounded lobe on its external edge, lobe with terminal crown of setae; meso- and metatibiae with transverse ridge near middle of external surface. Apalonychus species differ from Procoilodes species because the anterior margin of the pronotum is not sinuate, the eyes are clearly visible in dorsal view, and the humeral umbone is not developed. Coilodes species differ from Procoilodes species because the anterior margin of the pronotum is not sinuate, and the humeral umbone is not developed. The Tyrannasorus species differs from Procoilodes species because of its weakly concave antennal club, truncate clypeus, and smooth-surfaced scutellum.

Etymology. From the Latin prefix pro-, meaning "before," combined with the closely related generic name Coilodes.

\section{Procoilodes adrastus Ocampo, new species}

$$
\text { (Figs. 1-4) }
$$

Type Material. Holotype from the Dominican Republic (specimen number AMNH DR-10-136) embedded in Miocene amber. Holotype deposited in the Amber Fossil Collection, Dept. of Entomology, American Museum of Natural History, New York.

Description. Holotype. Length $4.73 \mathrm{~mm}$; greatest width $2.76 \mathrm{~mm}$. Color dark brown. Head. Frons with surface heavily and finely tuberculate, vertex with 2 conical tubercles. Eye canthus elongate, rectangular, apex truncate. Frontoclypeal suture not visible. Clypeus with surface similar to that of frons; anterior margin slightly rounded, lateral margins arcuate and narrowly reflexed. Eyes subglobose. Mandibles large; external edge broadly rounded; dorsal surface rugose, concave; subapex with well-developed, dorsal tooth. Maxilla and galea with dense setae; maxillary palpus with 4 segments. Labium with sparse, long setae. Pronotum. Surface weakly convex, heavily and finely tuberculate, slightly depressed on middle in anterior half. Edges of anterior angles, lateral margin, and sides of posterior margin smooth. Scutellum. Shape subtriangular; apex acute. Elytra. Surface shagreened, with 1 stria next to elytral suture. Humeral umbone elevated. Legs. Protibiae (Fig. 3) on external margin with 3 long, acute teeth and with 2 denticles between both apical and median and between median and basal teeth, and with 5 denticles behind basal tooth; apical spur not reaching apex of second tarsal segment. Protarsus with segments 1-4 subequal in length and each shorter than fifth, each with slender distal setae. Meso- and metatarsi with segments 1 and 5 longer than any of segments 24, segments 1-4 with slender distal setae.

Remarks. The tree that produced the resin that trapped this specimen is Hymenaea protera Poinar (Leguminosae, Caesalpinioidea). The amber in which it is embedded was dated as Miocene in age (Grimaldi 1995).

Etymology. From the classical mythological name "Adrastus," which means "he who holds his position" or "the unescapable," a name perfectly applied to this specimen which has been embedded and immovable in amber for more than 15 million years. 


\section{Acknowledgments}

I thank David Grimaldi (American Museum of Natural History, NY) for making the specimen available to me for study. I am grateful to Brett Ratcliffe and Mary Liz Jameson (University of Nebraska, Lincoln, NE) for their guidance in preparing the manuscript. Two anonymous reviewers are thanked for their helpful remarks to improve the manuscript. This project was supported by an NSF/ Biotic Survey and Inventory Grant (DEB 9870202) to B. C. Ratcliffe and an NSF/ PEET grant (DEB 9712447) to B. C. Ratcliffe and M. L. Jameson.

\section{Literature Cited}

Arrow, G. J. 1903. On the laparostict lamellicorn Coleoptera of Grenada and St. Vincent (West Indies). Transactions of the Entomological Society of London 4:509-520.

Castelnau, F. L. 1840. Historie naturelle des insectes coléoptères, avec une introduction renferant l'anatomie et la physiologie des animaux articulés, par M. Brullé. Tome deuxième. Duménil, Paris.

Grimaldi, D. 1995. The age of the Dominican amber [pp. 203-217]. In: Amber, Resinite, and Fossil Resins (K. B. Anderson and J. C. Crelling, editors). American Chemical Society Symposium Series 617, Washington, D.C.

Iturralde-Vinent, M. A., and R. D. E. MacPhee. 1999. Paleogeography of the Caribbean Region: implications for Cenozoic biogeography. Bulletin of the American Museum of Natural History 238:1-95.

Ivie, M. A. 1998. Hybosoridae of the West Indies. http://virgin.msu.montana.edu/ WestIndies/Polyphaga/Scarabaeoidea/index.html

Ratcliffe, B. C., and F. C. Ocampo. 2001. Tyrannasorus rex Ratcliffe and Ocampo, a new genus and species of Miocene hybosorid in amber from the Dominican Republic (Coleoptera: Scarabaeoidea: Hybosoridae). The Coleopterists Bulletin 55: 351-355.

Reiche, L. J. 1853. Note sur l'Hybosorus arator Auctorum, et sur le Trox granulatus, F, et description d'une nouvelle espèce. Annales de la Société Entomologique du France 1:87-90.

Westwood, J. O. 1846. On the lamellicorn beetles which possess exserted mandibles and labrum, and 10-jointed antennae. Transactions of the Entomological Society of London 4:155-180.

(Received 24 October; accepted 5 January 2001) 